\title{
DAKWAH FARDIYAH MELALUI PERNIKAHAN SECARA ISLAM PADA MASYARAKAT SAMIN (SEDULUR SIKEP) DI DUSUN BOMBONG DESA BATUREJO KECAMATAN SUKOLILO KABUPATEN PATI
}

\author{
Zulfi Trianingsih, Maryatul Kibtiyah, Anila Umriana \\ Fakultas Dakwah dan Komunikasi UIN Walisongo Semarang \\ Email: zulfitrianingsih9@gmail.com
}

\begin{abstract}
This study is a qualitative research that aims to describe and explain the customary marriage of the Islamic Society of Samin and the analysis of da'wah fardiyah to the Islamic marriage of Samin (Sedulur Sikep) community in Bombong Village Baturejo Village Sukolilo District Pati Regency. This type of research is a qualitative research. The source of research data is the marriage perpetrators of Islam between the Samin community and Muslims, the head of the Office of Religious Affairs (KUA) and the wife of one of the Samin community elders. Methods of data collection using interviews, observation, and documentation. Methods of data analysis using Miles and Huberman model, including data reduction, display data, conclusion. The results showed that Islamic marriage Samin society consists of several stages of application, pengislaman / shahada, marriage ceremony and prayer. Da'wah fardiyah on the Samin community has a tendency of the Islamic party to be da'i in his family which is shown by his advice in daily activities to carry out the command of Allah in accordance with Islamic Shari'a.
\end{abstract}

Penelitian ini merupakan penelitian kualitatif yang bertujuan untuk mendiskripsikan dan menjelaskan adat pernikahan Islam Masyarakat Suku Samin dan analisis dakwah fardiyah terhadap pernikahan Islam masyarakat Samin (Sedulur Sikep)di Dusun Bombong Desa Baturejo Kecamatan Sukolilo Kabupaten Pati. Jenis penelitian ini merupakan penelitian kualitatif. Sumber data penelitian adalah pelaku pernikahan secara Islam antara masyarakat Samin dan orang Islam, penghulu Kantor Urusan Agama (KUA) dan isteri salah satu sesepuh masyarakat Samin. Metode pengumpulan data menggunakan wawancara, observasi, dan dokumentasi. Metode analisis data menggunakan model Miles dan Huberman, meliputi data reduction, data display, conclusion. Hasil penelitian menunjukkan bahwa pernikahan Islam masyarakat Samin terdiri dari beberapa tahap yaitu lamaran, pengislaman/syahadat, akad nikah dan doa. Dakwah fardiyah pada masyarakat Samin memiliki kecenderungan pihak Islam menjadi da'i dalam keluarganya yang ditunjukkan dengan nasehatnya dalam aktivitas seharihari untuk menjalankan perintah Allah sesuai dengan syariat Islam.

Key word: Dakwah Fardiyah, Pernikahan Islam, Masyarakat Samin (Sedulur Sikep). 


\section{A. Pendahuluan}

Indonesia kaya akan budaya yang beraneka ragam, budaya Indonesia ini dihasilkan oleh suku-suku bangsa di Indonesia yang berjumlah ratusan dengan segala corak budayanya yang berbeda satu sama lain. Akan tetapi, perbedaan ini diikat oleh tali persatuan dalam satu bangsa yaitu Bangsa Indonesia. Menurut indeks dari kedua jilid Ensiklopedia Suku-suku Bangsa di Indonesia yang ditulis oleh ahli antropologi J.M. Melalatoa, jumlah suku bangsa di Indonesia adalah hampir 500 suku bangsa, sedang dalam Ensiklopedia Suku Bangsa di Indonesia karya ahli antropologi Zulyani Hidayah tercantum sebanyak 656 suku bangsa. ${ }^{1}$

Salah satu suku yang terdapat di Indonesia yaitu Suku Samin. Tersebar pertama kali di daerah Klopoduwur, Blora, Jawa Tengah. Pada 1890 pergerakan Samin berkembang di dua desa hutan kawasan Randublatung, Blora, Jawa Tengah. Gerakan ini lantas dengan cepat menjalar ke desa-desa lainnya. Mulai dari pantai utara Jawa sampai ke seputar Pegunungan Kendeng Utara dan Kendeng Selatan, atau sekitar perbatasan provinsi Jawa Tengah dan Jawa Timur menurut peta sekarang. Salah satu komunitas penganut Suku Samin berada di daerah Kabupaten Pati, lebih tepatnya yaitu di dusun Bombong desa Baturejo Kecamatan Sukolilo Kabupaten Pati. Salah satu suku diantara masyarakat Jawa yang dianggap feodal sekalipun terdapat sekelompok masyarakat yang dengan nilai-nilai yang egaliter, masyarakat suku samin ini juga di kenal sebagai Sedulur Sikep. ${ }^{2}$

Berdasarkan laporan monografi Luas Desa Baturejo adalah 963.546 HA, yang terdiri dari tanah pertanian dan pekarangan. Desa ini mempunyai empat dukuh, yaitu dukuh Bombong, Ronggo, Bacem, dan Mulyoharjo, yang terbagi dalam 23 rukun tetangga (RT). Masyarakat Samin kebanyakan tinggal di Dukuh Bombong (RW II) di RT 1 dan RT 2. Rumah Samin secara sekilas tidak ada bedanya dengan warga lainnya yaitu rumah berbentuk limasan, sebagian ada yang masih dari Bambu, Kayu dan tembok, bahkan banyak yang rumahnya sudah lebih baik. Desa Baturejo merupakan salah satu desa dari 16 desa yang berada di wilayah kecamatan Sukolilo Kabupaten Pati Propinsi Jawa Tengah. Wilayah kabupaten Pati memiliki luas 149.478 ha, terdiri dari 21 kecamatan, 5 kelurahan dan 400 desa. Wilayah Pati sebelah utara berbatasan dengan Laut Jawa, di sebelah timur berbatasan dengan Laut Jawa dan Kabupaten Rembang, sebelah Selatan

${ }^{1}$ Koentjaraningrat. Pengantar Antropologi. Jakarta: Rineka Cipta. 1998. Hlm:4.

2 Utomo, S Laksanto. Budaya Hukum Masyarakat Samin. Bandung: PT. Alumni. 2013, hlm: 191. 
berbatasan dengan Kabupaten Blora dan Purwodadi, sedangkan di sebelah barat berbatasan dengan Kabupaten Kudus dan Jepara.

Paham Samin atau Saminisme tidak membeda-bedakan agama, oleh karena itu orang samin tidak pernah mengingkari atau membenci agama, yang penting adalah tabiat dalam hidupnya. Paham Saminisme juga dinamakan agama Nabi Adam, sebab ajaran saminisme yang terwariskan hingga kini sebenarnya mencuatkan nilai-nilai kebenaran, kesederhanaan, kebersamaan, keadilan, dan kerja keras. Ajarannya meliputi ojo drengki srei, tukar padu, dahpen kemiren, ojo kutil jumput, mbedhog colong, nemu barang teng ndalan mawon disimpangi, artinya jangan berhati jahat, bertengkar mulut, iri hati, rakus dan mencuri, bila menjumpai barang di jalan dijauhi. ${ }^{3}$

Kesan pertama masyarakat Samin berwujud kesederhanaan hidup, pakaian apa adanya dengan celana tanggung, bertutur bahasa dengan yang tidak banyak bercampur bahasa lain. Masyarakat Samin adalah komunitas yang konsisten dalam berperilaku antara lain menjunjung tinggi nilai kejujuran, tidak iri, dengki, tidak berprasangka jelek pada orang lain, bersikap dan bertindak apa adanya (tidak mengada-ada). Bagi mereka yang penting tidak mengganggu orang lain dan sebaliknya mereka tidak mau orang lain mengganggu mereka. Menurut ajaran Saminisme, orang itu harus rajin bekerja jangan mencuri milik orang lain dan apabila ada seseorang minta sesuatu barang milik orang lain, maka orang itu wajib memberikan.

Masyarakat Samin bukanlah masyarakat yang tertinggal, bukan pula masyarakat yang terasing dan tidak mengindikasikan kelompok etnis tertentu yang diturunkan melalui ikatan darah. Ini berbeda dengan konotasi masyarakat adat sebagai sebuah masyarakat yang terikat oleh pertalian darah dan asal usul, meski simbol-simbol yang digunakan masyarakat Samin adalah simbol Jawa, namun nilai-nilai khas dan unik yang ada sedikit berbeda pendalaman maknanya dari apa yang kita kenal sebagai budaya Jawa. ${ }^{4}$

Pandangan hidup dan keyakinan Masyarakat Sikep yang dihayati dan dilampahi (dijalani) secara patuh dan konsekuen telah membangunkan adat-istiadat tertentu dan spesifik, sehingga tampak nyata menjadi budaya tersendiri yang membedakan mayarakat Sikep dari lingkungan sosial yang

3 Utomo, S Laksanto. Budaya Hukum Masyarakat Samin. Bandung: PT. Alumni. 2013, hlm: 212.

${ }^{4}$ Wahono, dkk. Budi Baik Siregar dan Wahono (Ed.). Mempertahankan Nilai dari Gesekan Zaman Kembali Ke Akar. Jakarta: Forum Pengembangan Partisipasi Masyarakat. 2002.hlm:117. 
lebih luas yaitu masyarakat budaya Sikep. Masyarakat Jawa yang kebetulan bersaudara kandung dengan orang-orang yang menjalani keyakinan Sikep dan rumahnya berada di pedukuhan warga Sikep mengakui adanya perbedaan ini. Oleh karena itu, bisa dimengerti jika ahli antropologi, M. Junus Melalatoa, menggolongkan masyarakat Sikep sebagai salah satu "suku" tersendiri diantara beraneka macam suku (etnis) lain di Indonesia dengan sebutan Wong Samin. ${ }^{5}$

Adat perkawinan warga Sikep ini tidak melewati prosedur formal dihadapkan pejabat pemerintah yang mewakili salah satu agama resmi yang diakui Negara. Oleh orang beragama disekitar yang beragama Islam santri, seringkali perkawinan Sikep itu dianggap sebagai tidak sah dan dipoyoki (dicemooh) seperti "kumpul kebo" saja. Masyarakat Samin memiliki pemikiran yang cenderung lugu, kritis dan menggunakan logika. Mereka jujur dan tidak suka berbohong, oleh karena itu mereka tidak suka berdagang karena menganggap berdagang itu penuh dengan kebohongan. Mereka lebih menyukai bekerja di sawah yang mereka miliki dan memanfaatkan hasil alam yang ada. Mereka memiliki kekerabatan yang sangat erat dan saling berkunjung ke rumah kerabatnya sesama Samin untuk menjaga hubungan kekerabatan yang baik antar sesama masyarakat Samin.

Budaya politik yang terdapat dalam Masyarakat Samin merupakan sistem nilai dan keyakinan yang dimiliki bersama oleh masyarakat terutama Samin (Sedulur Sikep) di dusun Bombong Desa Baturejo Kecamatan Sukolilo Pati. Budaya politik merupakan refleksi terhadap orientasi, sikap dan perilaku masyarakat dalam merespon setiap objek dan proses politik yang telah sedang dan akan terjadi. Hubungan pemerintah dengan masyarakat Samin berjalan selaras dan harmonis. Dalam kehidupan bermasyarakat pasti terdapat organisasi kemasyarakatan yang terdapat dalam lingkungan tempat tinggal, karena manusia hidup bersosial dan berkomunikasi untuk menuju perubahan sosial yang lebih baik. ${ }^{6}$

Berdasarkan struktur sosial-keagamaan warga Sukolilo, khususnya di desa Baturejo sangat unik dan menarik. Islam merupakan agama terbesar di Desa Baturejo. Terdapat beragam organisasi masyarakat dan mereka hidup saling berdampingan karena sudah mempunyai wilayah

5 Utomo, S Laksanto. Budaya Hukum Masyarakat Samin. Bandung: PT. Alumni. 2013.hlm: 192-193.

${ }^{6}$ Munadi. "Budaya Politik Masyarakat Samin (Sedulur Sikep) di dusun Bombong Desa Baturejo Kecamatan Sukolilo Pati”, dalam Jurnal Ilmu Politik ,Vol. 4, No. 1, Januari, 2013.hlm: 69-79. 
masing-masing. Dalam suasana keagamaan yang seperti itu terdapat sekelompok komunitas Samin yang mengaku menganut agama Adam, hal tersebutlah yang menjadi salah satu alasan pentingnya penelitian tentang masyarakat Samin. Respon organisasi masyarakat terhadap masyarakat Samin baik-baik saja, saling menghargai satu sama lain. Karena organisasi masyarakat sudah paham dengan karakteristik masyarakat Samin, sehingga dapat hidup dalam satu lingkup dengan solidaritas yang tinggi. Namun akhir-akhir ini banyak masyarakat Samin yang mulai masuk Islam.

Dakwah memiliki tujuan yaitu meng-Esakan Allah SWT, membuat manusia tunduk kepada-Nya, mendekatkan diri kepada-Nya dan introspeksi terhadap apa yang telah diperbuat. Sebuah materi dakwah yang akan disampaikan kepada objek dakwah membutuhkan metode yang tepat dalam menyampaikannya. Terdapat beberapa kerangka dasar tentang model dakwah sebagaimana terdapat pada QS. An-Nahl 125 yaitu bi al hikmah (kata hikmah sering diartikan bijaksana adalah suatu pendekatan sedemikian rupa sehingga objek dakwah mampu melaksanakan apa yang didakwahkan atas kemauannya sendiri, tidak merasa ada paksaan, konflik maupun rasa tertekan. Dengan kata lain bi al hikmah merupakan suatu metode pendekatan komunikasi yang dilakukan atas dasar persuasif), mau'idzah hasanah (yaitu nasehat yang baik, berupa petunjuk ke arah kebaikan dengan bahasa yang baik yang dapat mengubah hati agar nasehat tersebut dapat diterima), mujadalah (diskusi).

Sejarah mencatat penyebaran agama Islam dapat melalui berbagai cara, yaitu melalui perdagangan jual-beli, perkawinan, pendidikan, politik dan seni budaya. Berdasarkan wawancara peneliti dengan salah satu pemuka agama di dusun Bombong desa Baturejo, penyebaran agama Islam pada masyarakat Samin melalui perkawinan yaitu masyarakat non Samin yang beragama Islam menikahi masyarakat Samin dan menyisipkan nilainilai ajaran agama Islam melalui dakwah fardiyah sehingga anak keturunannya mengikuti masuk agama Islam dan menempuh pendidikan formal sebagaimana masyarakat pada umumnya. Bagi peneliti hal tersebut merupakan hal yang menarik untuk diteliti.

\section{B. Dakwah Fardiyah}

\section{Pengertian Dakwah Fardiyah}

Dakwah fardiyah sebagai antonim dari dakwah jama'iyah atau 'ammah ialah ajakan atau seruan ke jalan Allah yang dilakukan seorang $d a$ ' $i$ (penyeru) kepada orang lain secara perseorangan dengan tujuan 
memindahkan al mad'u pada keadaan yang lebih baik dan diridhai Allah. Perubahan atau perpindahan tersebut adakalanya dari kekafiran kepada keimanan, dari kesesatan dan kemaksiatan kepada petunjuk dan ketaatan, dari sikap ananiyah (individualisme) dan chauvinisme kepada sikap mencintai orang lain, mencintai amal jama'i atau kerja sama, dan senang kepada jamaah, atau adakalanya memindahkannya dari sikap acuh tak acuh dan tidak peduli menjadi sikap komitmen terhadap Islam, baik akhlaknya, adabnya, dan manhaj (sistem) kehidupannya yang sudah tentu perpindahan ini menuju arah yang lebih baik dan lebih diridhai Allah SWT. ${ }^{7}$

\section{Metode Dakwah Fardiyah}

Dakwah fardiyah (da'i dan mad'u masing-masing satu orang) bagi solusi konflik antar individu dalam suatu budaya. Metode-metode yang digunakan dalam dakwah fardiyah menurut Aripudin antara lain: ${ }^{8}$

a. Hikmah pendekatan ilmiah, bentuk tindakannya yaitu berkata jujur, berbicara sesuai objeknya, sistematis, dukungan fakta, singkat dan padat.

b. Mauizhah Hasanah dengan menjadi seorang teladan yang baik, memberikan pelajaran yang benar tepat untuk anak-anak dan orang awam (umum).

c. Mujadalah bi al-lati hiya ahsan yaitu dengan berdialog, berdebat, dan diskusi tepat dilakukan ketika berhadapan dengan kaum intelek terpelajar, para alim, dan kaum pembantah.

d. Ta'aruf maksudnya yaitu pertukaran budaya positif antara satu sama lain.

e. Ishlah artinya perbaikan yang mana sikap moderat sangat dituntut dalam metode ini.

f. Tilawah yaitu pembacaan kebenaran universal.

g. Taushiyah dengan cara saling berwasiat dalam kebaikan termasuk didalamnya kritik konstruktif.

h. Ta'lim yaitu pembelajaran yang dapat dilakukan dengan cara presentasi dan dialog.

i. Uswah hasanah yaitu dengan cara memberikan percontohan yang baik menyatu didalamnya bahwa ucapan dan perbuatan mesti seirama dan sama.

7 Mahmud, A A Halim. Dakwah Fardiyah Metode Membentuk Pribadi Muslim. Jakarta: Gema Insani. 1995.HIm:29.

8 Aripudin, Acep. Dakwah Antarbudaya. Bandung:Remaja Rosdakarya. 2012.Hlm:39. 


\section{Wasilah Khusus Dakwah Fardiyah}

Wasilah yang dimaksud disini adalah semua jalan yang dapat mengantarkan da'i untuk mencapai tujuan dakwah. Wasilah khusus dakwah fardiyah dilakukan sesuai dengan situasi sosial yang ada. Adapun wasilah khusus dakwah fardiyah yaitu: ${ }^{9}$

a. Hubungan Pribadi dengan Mad'u

Hubungan ini merupakan ciri sekaligus menjadi tuntutan pokok dakwah fardiyah. Walaupun tempaknya terbatas, tetapi hal ini dapat berkembang lebih lanjut hingga pada hubungan pribadi yang sangat kokoh serta menumbuhkan rasa cinta dan saling percaya. Hubungan ini bermula dari ta'aruf, lalu dilanjutkan dengan perkenalan yang lebih dekat yang menjadikan hubungan antara penerima dakwah dan da'i bagaikan lembaran kertas yang bersih tidak tertutup oleh sesuatu apapun.

Tahap ta'aruf ini harus menumbuhkan rasa saling menyayangi, saling mencintai, dan saling memahami. Dengan demikian akan timbul kesamaan persepsi mengenai suatu masalah, bahkan mengenai manusia, hal atau peristiwa, dan mengenai amal serta aktivitas, kemudian tumbuh perasaan saling menjaga, saling memperhatikan kepentingan masing-masing, saling menolong dan membantu hingga keberadaan mad'u selalu dalam lapangan iman.10

Hubungan pribadi yang demikian akan menimbulkan rasa cinta, senang melaksanakan amal untuk Islam, cinta amal jama'i, dan selanjutnya menumbuhkan rasa persaudaraan karena Allah dan saling bertemu dalam rangka melaksanakan ketaatan kepada Allah SWT.

b. Pengertian Baik terhadap Kecenderungan Mad'u

Pengertian yang dimaksud disini adalah pengetahuan da'i tentang jiwa mad'u beserta semua sifat, watak, dan kecenderungannya. Pengetahuan ini merupakan kunci untuk membuka hati mad'u dan sebagai obor yang dapat menerangi dunia manusia yang paling dalam yakni jiwa. Jiwa manusia merupakan dunia yang sangat luas jangkauannya. Di dalam jiwa ada perasaan, kecenderungan, keinginan, watak, cita-cita dan sebagainya yang tak dapat diukur dan dibatasi. ${ }^{11}$

9 Mahmud, A A Halim. Dakwah Fardiyah Metode Membentuk Pribadi Muslim. Jakarta: Gema Insani. 1995.HIm: 141.

10 Mahmud, A A Halim. Dakwah Fardiyah Metode Membentuk Pribadi Muslim. Jakarta: Gema Insani. 1995.Hlm:142.

11 Mahmud, A A Halim. Dakwah Fardiyah Metode Membentuk Pribadi Muslim. Jakarta: Gema Insani. 1995.HIm:143. 
Keberhasilan hubungan antara seorang da'i dan penerima dakwah bergantung pada pengetahuannya tentang cara menggali tabiat manusia. Untuk mengetahui hal ini diharapkan juru dakwah tidak mengandalkan ilmu jiwa modern saja yang hanya mengamati gejalagejala serta terapinya menurut pendapat dan pemikiran masing-masing psikolog. Namun dengan cara merenungkan ayat-ayat Al-Qur'an. ${ }^{12}$

c. Sabar terhadap Mad'u

Kesabaran dalam dakwah haruslah dimiliki oleh seorang da'i. Dalam keadaan bagaimanapun da'i tetap dituntut untuk berlaku sabar, bahkan harus tetap menghiasi dirinya dengan sifat-sifat yang baik. Tidak ada sesuatu yang lebih berbahaya bagi manusia selain kehilangan kesabaran. Karena kehilangan kesabaran akan menyebabkan kehilangan ketenangan, keseimbangan, rasionalitas dan kemampuan dalam melahirkan kebijakan-kebijakan terhadap manusia maupun terhadap sesuatu yang menjadi landasan pergaulan yang baik.

Nilai seorang da'i belumlah teruji kecuali setelah bergaul dengan orang lain, baik dengan mereka yang taat dan suka melanggar, dengan mereka yang mukmin dan kafir, ataupun dengan orang yang saleh dan thaleh (buruk/jahat). Dalam pergaulan tersebut tidak ada sesuatu yang lebih diperlukan selain kesabaran.

\section{Mengenal Masyarakat Samin di Dusun Bombong Desa Baturejo Kecamatan Sukolilo Kabupaten Pati}

Mata pencaharian masyarakat Samin (sedulur sikep) mayoritas adalah petani, mereka menghindari pekerjaan yang berbau perdagangan yang mengambil dari produsen atau dalam istilah jawa yaitu dagang kulak karena perdagangan bukan ajaran dari moyang mereka. Masyarakat samin juga beranggapan bahwa berdagang memiliki potensi untuk berbohong, sedangkan mereka tidak suka dengan kebohongan. Namun masyarakat Samin yang sudah Islam tidak terlalu kaku dengan ajaran nenek moyang yang pernah ia dapatkan sewaktu masih Samin, masyarakat Samin yang sudah Islam mulai terbuka dengan kondisi sosial yang ada, ada yang mulai berdagang dan juga membuka usaha seperti bengkel, toko material, warung, penggilingan padi dan lain sebagainya.

Tingkat pendidikan Desa Baturejo tidak terlalu tinggi. Hanya beberapa saja yang lulus dari Perguruan Tinggi. Bahkan penduduk yang

12 Mahmud, A A Halim. Dakwah Fardiyah Metode Membentuk Pribadi Muslim. Jakarta: Gema Insani. 1995.Hlm:143. 
tidak bersekolah tingkatnya cukup tinggi di desa ini. Hal ini terjadi karena masyarakat sedulur sikep enggan menyekolahkan anak-anaknya. Alasan mereka tidak menyekolahkan anak-anak mereka adalah sekolah bukan salah satu ajaran dari nenek moyang mereka. Kalaupun ada hanya segelintir saja yang bersekolah, itupun belum tentu lulus Sekolah Dasar. Keterangan lebih rinci terdapat dalam tabel berikut:

Tabel I

Jumlah penduduk Berdasarkan Pendidikan

\begin{tabular}{|c|c|c|}
\hline No & Tingkat Pendidikan & Jumlah \\
\hline 1 & Tamat Akademik/Perguruan Tinggi & 35 \\
\hline 2 & Tamatan SLTA & 190 \\
\hline 3 & Tamatan SLTP & 452 \\
\hline 4 & Tamatan SD & 894 \\
\hline 5 & Tidak Tamat SD & 99 \\
\hline 6 & Belum Tamat SD & 223 \\
\hline 7 & Tidak Sekolah & 421 \\
\hline & Jumlah & $\mathbf{2 3 1 4}$ \\
\hline
\end{tabular}

Sumber : Data Monografi Desa Baturejo tahun 2016

Angka pada kolom tidak bersekolah cukup tinggi, kenyataan tersebut didukung oleh jumlah anak-anak sedulur sikep yang tidak bersekolah. Alasan sedulur sikep tidak menyekolahkan anak-anak mereka adalah tidak mau apabila anak turunan mereka sekolah dididik untuk menjadi orang yang pintar kemudian pintar mengelabuhi orang lain, karena kebanyakan orang yang korupsi adalah karena mereka pintar. Namun anak-anak keturunan hasil pernikahan silang antara Samin dan Islam sudah mulai bersekolah selayaknya anak-anak pada umumnya. Sebagaimana hasil wawancara dengan salah satu pemuka agama Islam yaitu Bapak KH. Nur Hamid pada tanggal 17 November 2016 pukul 16.12 WIB di rumah beliau di Dusun Bombong: 
"Wong Samin ora sekolah amergo wedi nek pinter mbak, nek wis pinter mesti mengko pinter ngakali wong liyo, mulane akeh wong sing korupsi amergo pinter wis reti carane korupsi, wong Samin kui ra iso moco nulis, nganggone ilmu titen, wong Samin yo nduwe HP tapi ora iso moco SMS, nek ono SMS kon moco tanggane sing iso moco, misale ameh telpon wong liyo nganggone ilmu titen, ee..misale nomere kang Sobari ning HP yo dijengeni sak menyete, misale kepencet ongko limo yo berarti nomer limo kui nomere kang Sobari, wong Samin nganggep yen tulisan yo kui anake dianggep tulisan. Tapi yen anak-anake Samin sing wis Islam yo gelem sekolah, gelem ngaji koyok koncokonco liyane".

Masyarakat Samin tidak bisa membaca dan menulis melainkan menggunakan ilmu titen, ingatan mereka sangat kuat. Masyarakat Samin menganggap bahwa anak mereka adalah tulisan mereka. Namun sekarang ini sudah banyak pemuda Samin yang bisa membaca, karena lingkungan mereka yang sering berkumpul dengan pemuda sebaya yang bisa membaca. Hampir semua pemuda Samin sudah memiliki HP, bahkan anakanak Samin sudah banyak yang pegang gadget, walaupun sekedar untuk permainan saja. Kebanyakan yang mau bersekolah adalah anak-anak hasil pernikahan silang (Samin dan Islam), yang tidak menikah silang alias Samin tidak sekolah. Anak hasil pernikahan silang antara Samin dan Islam sudah selayaknya seperti anak-anak lainnya yaitu bersekolah, bisa membaca dan menulis juga mengikuti TPQ (Taman Pendidikan AlQur'an).13

Masyarakat sedulur sikep yang berada di Desa Baturejo berjumlah cukup besar dengan menganut agama Adam. Pemukiman masyarakat ini berada di Dusun Bombong. Dusun Bombong terhitung merupakan pusat wilayah dari masyarakat sedulur sikep di Sukolilo. Selain itu, sampai sekarang musyawarah sedulur sikep terpusat di Dusun Bombong Desa Baturejo. Keterangan lebih rinci mengenai agama penduduk Desa Baturejo terdapat pada tabel berikut:

13 wawancara, KH. Hamid, 17 November 2016 
Tabel II

Jumlah Pemeluk Agama

\begin{tabular}{|c|c|c|}
\hline No & Agama & Jumlah \\
\hline 1 & Islam & 5299 \\
\hline 2 & Kristen Katolik & 4 \\
\hline 3 & Kristen Protestan & - \\
\hline 4 & Budha & - \\
\hline 5 & Hindu & - \\
\hline 6 & Lainnya & 803 \\
\hline
\end{tabular}

Sumber : Data Monografi Desa Baturejo tahun 2016

Keyakinan masyarakat Samin (sedulur sikep) termasuk dalam kolom agama Lainnya, karena agama yang mereka anut adalah agama Adam, sedangkan agama Adam tidak termasuk dalam agama yang diakui di Indonesia. Agama Adam lebih tepatnya disebut sebagai keyakinan atau kepercayaan yang diyakini oleh sedulur sikep (samin). Di dalam lingkungan sikep, mereka lebih nyaman menyebutnya sebagai wong dam atau orang yang menganut kepercayaan Adam.

Masyarakat sedulur sikep merupakan ciri khas Desa Baturejo dengan menganut agama Adam. Berdasarkan data dari kepala Desa Baturejo bahwa kurang lebih terdiri dari 210 kartu keluarga sedulur sikep. Pemukiman masyarakat sedulur sikep berpusat pada 1 dusun yaitu dusun Bombong. Ciri khas dari masyarakat Samin dapat terlihat dari pemukiman yang sejajar dalam satu blok. Selain itu, sedulur sikep enggan menyekolahkan anak-anaknya. Kalaupun ada hanya beberapa saja yang sekolah, itupun tidak tamat SD. Hal itulah yang menyumbangkan angka pendidikan cukup besar pada golongan yang tidak sekolah. Mata pencaharian utama sedulur Sikep adalah petani, hal tersebut salah satunya karena moyang mereka mengajarkan pekerjaan sejak kecil yaitu sebagai petani dan memanfaatkan hasil bumi secara alami. Sebagai contoh menggunakan kayu kering sebagai bahan bakar.

Masyarakat sedulur sikep yang dinikahi oleh masyarakat non sikep yang beragama Islam kebanyakan diboyong atau dibawa ke rumah pihak yang beragama Islam, entah masih tinggal bersama mertua atau membuat rumah sendiri. Hal tersebut sesuai dengan kesepakatan kedua belah pihak, 
namun kebanyakan pihak sikep ikut dengan pihak Islam. Orang tua pihak sikep sudah lilo legowo anaknya (perempuan) dibawa suaminya. Sebagaimana pernyataan Bapak Musdi seorang Modin Dusun Bombong:

"Wong Samin wedok nek ntuk wong Islam yo ntuk digowo bojone mbak, wong tuane ora ngrawehi, yo angger dipek bojo sopo wae mesti gelem, jaman mbiyen kan ora ntuk yen anake ntuk bojo selain Samin, saiki ntuk amergo lahan semakin sempit wis padat penduduk, kan Samin modele rumahe tinggal satu blok deretan, misale anake ntuk wong njobo nek dirawehi lha terus piye, dadine saikine nek ntuk sopo wae yo gelem"14

Masyarakat sedulur sikep memiliki ingatan yang kuat yaitu menggunakan ilmu titen, sebagaimana sesuai dengan cerita yang sudah umum di masyarakat luas bahwa apabila ada seseorang yang agak nyeleneh pasti menyebutnya sebagai Samin, padahal masyarakat luas belum tentu tau apa yang dimaksud Samin. Sebagaimana sesuai dengan cerita yang sudah beredar luas dan berdasarkan pengalaman pribadi penulis serta diperkuat oleh wawancara dengan Bapak KH. Nur Hamid bahwa apabila bertamu ke rumah salah satu warga Samin dan ketika itu disuguhi makanan atau minuman maka makan atau minum saja seadanya sesuai yang disuguhkan, karena apabila tidak dimakan atau diminum maka suatu hari nanti apabila bertamu kembali di rumah tersebut maka tidak akan di suguhi lagi. Namun kita sebagai seorang muslim maka harus bisa memilah dan memilih makanan atau minuman yang disuguhkan. Seperti penjelasana Bapak KH.Nur Hamid:

"Nek aku moro dolan ning nggone wong Samin biasane ditawani ngumbe yo tak jawab banyu putih, misale di wei iwak pitik utawa iwak sing sembelihan ora tak pangan, kenopo? Amergo wong Samin ora Islam, dadi nek nyembelih kewan mesti ora nganggo bismilah lan ora sesuai syariat Islam, yen wis ngono berarti kewan kui termasuk haram utawa bangkai".

Sesuai dengan kutipan diatas bahwa apabila bertamu di rumah salah satu warga Samin dan ditawari makanan atau minuman, lebih aman menjawab dengan pilihan air putih, karena warga Samin tidak Islam maka kita harus berhati-hati dan memilah makanan, misal ditawari makanan

${ }^{14}$ wawancara, Musdi (Modin Dusun Bombong), 18 Februari 2017 
seperti daging ayam atau makanan yang di sembelih (dipotong) lebih baik tidak dimakan karena sudah pasti masyarakat Samin dalam memotongnya tidak menggunakan basmallah dan tidak menyembelih sesuai dengan syariat Islam, dengan begitu maka sudah dipastikan bahwa daging tersebut termasuk haram dan masuk dalam kategori bangkai. Beda cerita apabila dengan masyarakat Samin yang sudah Islam, tentu sudah mulai menyesuaikan dengan menggunakan syariat Islam.

\section{Sejarah Pernikahan Islam Masyarakat Samin (Sedulur Sikep) di Dusun Bombong Desa Baturejo Kecamatan Sukolilo Kabupaten Pati}

Salah satu suku yang terdapat di Indonesia yaitu Suku Samin. Tersebar pertama kali di daerah Klopoduwur, Blora, Jawa Tengah. Pada 1890 pergerakan Samin berkembang di dua desa hutan kawasan Randublatung, Blora, Jawa Tengah. Gerakan ini lantas dengan cepat menjalar ke desa-desa lainnya. Mulai dari pantai utara Jawa sampai ke seputar Pegunungan Kendeng Utara dan Kendeng Selatan, atau sekitar perbatasan provinsi Jawa Tengah dan Jawa Timur menurut peta sekarang. Salah satu komunitas penganut Suku Samin berada di daerah Kabupaten Pati, lebih tepatnya yaitu di dusun Bombong desa Baturejo Kecamatan Sukolilo Kabupaten Pati. Salah satu suku diantara masyarakat Jawa yang dianggap feodal sekalipun terdapat sekelompok masyarakat yang dengan nilai-nilai yang egaliter, masyarakat suku samin ini juga di kenal sebagai Sedulur Sikep. ${ }^{15}$

Masyarakat Samin merupakan komunitas masyarakat yang menganut ajaran Samin (Saminisme). Ajaran Samin adalah salah satu suku yang ada di Indonesia. Masyarakat ini adalah keturunan para pengikut Samin Surosentiko yang mengajarkan sedulur sikep, dimana mereka mengobarkan semangat perlawanan terhadap Belanda dalam bentuk lain di luar kekerasan. Bentuk yang dilakukan adalah menolak membayar pajak, menolak segala peraturan yang dibuat pemerintah kolonial. Masyarakat ini sering memusingkan pemerintah Belanda maupun penjajahan Jepang karena sikap itu, sikap yang hingga sekarang dianggap menjengkelkan oleh kelompok di luarnya.

Penyebutan sebagai masyarakat Samin, wong Samin, wong dam (orang memeluk agama Adam) merupakan penamaan dari orang-orang

15 Utomo, S Laksanto. Budaya Hukum Masyarakat Samin. Bandung: PT. Alumni. 2013.Hlm:191. 
luar. Mereka sendiri menyebut diri mereka sebagai masyarakat Sikep, sehingga mereka lebih suka disebut masyarakat Sikep. Sebagai tuturan kepanjangannya adalah sikep alaki-rabi yaitu pria rabi (menikahi) wanita dan wanita alaki (menikahi) pria. Sementara sikep memuat dua arti: sikep (sikap) sebagai kata benda mempunyai makna bakohing kalbu (keteguhan hati atau kekuatan penentuan diri), sedangkan sikep (memeluk) sebagai kata kerja memuat makna paling positif "persatuan hati". Menurut mereka sebenarnya semua manusia dimana-mana sama saja melaksanakan kehidupan pria menikahi wanita dan wanita menikahi pria. Akan tetapi disadari bahwa hanya masyarakat merekalah yang mengemukakannya dalam pengakuan formal dan menyebutnya sebagai identitas kemasyakatan. ${ }^{16}$

Alam pikiran Samin jelas-jelas merupakan produk pikiran Jawa asli yang merupakan reduksi dari ajaran Trisula Wedha: Hindu-Budha, Kristen dan Islam. Wong Samin mengagungkan pendhawa lima dengan Puntadewa sebagai intinya. Puntadewa berjiwa polos lugu tidak pernah berdusta, tekun dalam pendalaman diri, tidak mau dicampuri orang lain dan sangat ahli dalam berargumen. Mereka meyakini, Samin (sami-sami amin = sama rata, sama sejahtera, sama mufakat) adalah dewa yang menitis ke dunia atau bathara kang kalingga sujanma. ${ }^{17}$

Pernikahan pada masyarakat Samin mengutamakan pada komunitasnya sendiri, sehingga kekerabatan hanya sekeliling komunitas mereka sendiri. Alasan pernikahan mengutamakan dengan komunitas sendiri adalah agar tidak susah-susah mengajarkan ajaran sedulur sikep karena sudah sepaham sehingga dalam melanjutkan hidup sudah satu ajaran. Namun kehidupan sosial yang ada di masyarakat tidak menutup kemungkinan masyarakat Samin bersosialisasi dengan masyarakat luar sehingga kenal dengan beberapa orang yang non Samin. ${ }^{18}$

"Sedulur sikep nek iso ntuk podo-podo sikep mbak, alesane yo ben ora usah ngajarke meneh, nek ntuk wong selain sikep kan kudu ngaweruhi ajaran-ajaran sikep, yen podo-podo sikep kan kepenak ora usah baleni meneh mbak, tinggal nglanjutke urip koyok opo sing pernah diajarke wong tuwo jaman biyen"

16 Utomo, S Laksanto. Budaya Hukum Masyarakat Samin. Bandung: PT. Alumni. 2013.Hlm:196.

17 Purwadi dan Enis Niken. Dakwah Walisongo Penyebaran Islam Berbasis Kultural di Tanah Jawa. Yogyakarta: Panji Pustaka. 2007.Hlm:252.

18 wawancara, Ibu Hartatik, 16 Februari 2017 
Awal mula pernikahan Samin dengan masyarakat non Samin yang beragama Islam sudah berlangsung sejak dulu, tidak bisa dipastikan mulai tahun berapa yang pasti sejak lama sudah ada masyarakat Samin yang menikah dengan orang Islam. Sebagaimana kutipan wawancara dengan Modin Dusun Bombong:

"Wis awit mbiyen pernikahane mbak, awit jaman kae yo wis ono, tepate tahun piro yo mboh lali, lha wong sing saiki wae wong Samin ntuk Islam ono sing wis tuwo kok mbak, wis nduwe putu. Yo wis melu Islam wong tinggale ning kampung Islam kok".

Pernikahan Islam dengan Samin sudah ada sejak dahulu, karena sudah ada pasangan keluarga yang dulu pada awalnya pihak istri berasal dari Samin, menikah dengan orang Islam dan sekarang sudah memiliki cucu. Keluarga tersebut sudah mengikuti ajaran agama Islam karena tinggal di kampung Islam. Pernikahan antara masyarakat Samin dan orang Islam awalnya mendapat penolakan dari pihak Samin, begitu juga pihak Islam tidak setuju dengan pernikahan tersebut. Masing-masing pihak memiliki alasan tersendiri. Pihak Samin memiliki alasan seperti yang sudah dijelaskan di atas dan pihak Islam memiliki alasan bahwa masyarakat Samin sudah terkenal dengan ajarannya yang dipegang teguh dan juga tidak beragam Islam. Citra negatif dari masyarakat terhadap masyarakat Samin sudah menyebar luas sehingga pihak Islam dalam menjaga nama baiknya tidak mau berurusan dengan pihak Samin.

Orang tua kedua belah pihak tidak sepakat dengan pernikahan tersebut, namun calon mempelai Samin dan non Samin Islam saling mencintai dan bersikukuh untuk menikah. Akhirnya orang tua kedua belah pihak menyerahkan kepada kedua calon mempelai, walaupun pihak orang tua Samin masih agak berat hati.

"Mbiyen awale aku yo dirawehi ntuk wong Islam mbak, kan modele wong sikep kudu ntuk podo-podo wong sikep, mbiyen aku ape dijodohke karo podo-podo sikep, tapi aku emoh luwih milih bojoku sing saiki senajan bojoku wong Islam. Lha aku dijak mlebu Islam, yo ora masalah sing penting aku nikah karo bojoku iki, wis kadung cinta kok mbak".19

${ }^{19}$ wawancara, Sumar 17 Februari 2017 
Seiring berjalannya waktu, masyarakat Samin yang menikah dengan orang Islam semakin bertambah dan sudah banyak. Sesuai dengan data pernikahan yang penulis peroleh dari Modin Dusun Bombong, walaupun pada catatan buku daftar pernikahan Modin tidak tercantum yang menikah itu statusnya dari komunitas Samin atau bukan namun Modin berusaha mengingat-ingatnya. Datanya sebagaimana berikut:

\section{Tabel III \\ Pernikahan dengan Orang Islam}

\begin{tabular}{|c|c|c|c|}
\hline Tahun & $\begin{array}{c}\text { Laki-laki Islam + } \\
\text { Perempuan } \\
\text { Samin }\end{array}$ & $\begin{array}{c}\text { Laki-laki Samin } \\
\text { + Perempuan } \\
\text { Islam }\end{array}$ & Jumlah \\
\hline $\mathbf{2 0 1 0}$ & 1 & 0 & 1 \\
\hline $\mathbf{2 0 1 1}$ & 1 & 0 & 1 \\
\hline $\mathbf{2 0 1 2}$ & 3 & 0 & 3 \\
\hline $\mathbf{2 0 1 3}$ & 3 & 0 & 3 \\
\hline $\mathbf{2 0 1 4}$ & 2 & 1 & 3 \\
\hline $\mathbf{2 0 1 5}$ & 2 & 0 & 2 \\
\hline $\mathbf{2 0 1 6}$ & 3 & 0 & 3 \\
\hline $\mathbf{2 0 1 7}$ & 0 & 0 & 0 \\
\hline Jumlah & $\mathbf{1 5}$ & $\mathbf{1}$ & $\mathbf{1 6}$ \\
\hline
\end{tabular}

Sumber: catatan daftar pernikahan Modin Dusun Bombong

Berdasarkan data di atas bahwa pihak laki-laki Islam mendominasi pernikahan antara Perempuan Samin dengan Laki-laki Islam. Data di atas dari tahun 2010 sampai 2017 memiliki trend kecenderungan kuantitas pernikahannya naik turun, sebenarnya pernikahan masyarakat Samin dengan orang Islam tidak dapat dipastikan cenderung naik atau cenderung turun karena pernikahan tersebut tidak pasti ada tiap tahunnya, dalam tiap tahunnya tidak dapat dipastikan ada pernikahan antara masyarakat Samin dengan orang Islam. Pernikahan tersebut merupakan bentuk akulturasi antara Samin dengan Islam. Dalam pernikahan tersebut dapat diakulturasikan dakwah Islam terhadap kehidupan sehari-hari. Sesuai 
dengan teori medan dakwah bahwa dakwah dapat dilakukan kapan saja, dimana saja dan kepada siapa saja.

Dakwah tidak menutup kemungkinan ada di keluarga masyarakat Samin yang menikah dengan orang Islam. Dakwah tersebut bisa dilakukan dengan jalan dakwah fardiyah yaitu antara perorangan (satu dai dan satu mad'u atau lebih) dalam kehidupan rumah tangganya pasca menikah. Nuansa dakwah tersebut sudah mulai terasa pada awal pernikahan dan pasca pernikahan dengan menyisipkan nilai-nilai keislaman dalam tiap aktivitas keluarganya.

\section{E. Penikahan Islam Masyarakat Samin (Sedulur Sikep) di Dusun Bombong Desa Baturejo Kecamatan Sukolilo Kabupaten Pati}

Tradisi perkawinan dalam masyarakat Samin merupakan salah satu budaya masyarakat yang selalu dipegang teguh, pola perkawinan menjadi pola kehidupan masyarakat. Perkawinan masyarakat Samin pada awalnya sama seperti ditempuh masyarakat lainnya, tetapi dalam proses ada hal-hal secara prinsip sama sekali berbeda. Sebagaimana pernyataan Ibu Hartatik seorang istri dari Kepala Suku Samin dalam wawancara tanggal 16 Februari 2017:

"Tradisi pernikahane Sedulur Sikep nggih sami mawon koyok umume mbak, iki tak cerita tentang aku ya mbak, carane kan aku gone bapak ibuku, nek ono wong lanang sing kekarep utawi pingin ngepek aku dadi bojone ya kudune teko ning bapak ibuku, nembung karo sing nduweni aku yo kui bapak ibuku, lha nek bapak ibuku wis setuju lagi dilanjutke tahap selanjute mbak., mulai dari nyuwito lan selanjute".

Sesuai dengan pernyataan hasil wawancara dengan Ibu Hartatik bahwa tradisi pernikahan sedulur sikep sama saja seperti pernikahan pada umumnya, dalam istilah sedulur sikep bahwa seorang wanita yang belum menikah adalah milik kedua orang tuanya, maka apabila ada seorang lakilaki yang ingin mempersuntingnya maka harus izin dengan yang punya wanita tersebut yaitu Bapak Ibunya, setelah diizinkan dan direstui maka bisa melanjutkan ke tahap selanjutnya. Berdasarkan wawancara dengan 
Ibu Hartatik (16 Februari 2017) adapun tahap-tahap perkawinannya yaitu:20

1. Nyumuk, adalah kedatangan keluarga calon kemanten putra ke keluarga kemanten putri untuk menanyakan apakah sudah mempunyai calon suami ataukah masih gadis (legan). Nyumuk dalam istilah masyarakat Samin disebut juga dengan "gunem/rembugan" (musyawarah/kesepakatan) keluarga.

2. Ngandek, adalah pernyataan calon besan dari keluarga kemanten putra kepada Bapak-Ibu calon kemanten putri untuk menindaklanjuti forum nyumuk. Pada proses ini, sang Ibu dari calon kemanten putra biasanya memberi cincin emas kepada calon kemanten putri (calon menantu) sebagai tanda telah diendek/diwatesi.

3. Nyuwito-ngawulo, adalah hari dimana dilangsungkan perkawinan yang didasari niat dari kemanten putra untuk meneruskan keturunan (wiji sejati, titine anak Adam). Setelah pasuwitan (nyuwito), biasanya kemanten putra hidup bersama keluarga kemanten putri dalam satu rumah, atau kemanten putri hidup bersama keluarga kemanten putra berdasarkan kesepakatan antar besan. Kesepakatan tersebut biasanya berdasarkan pada kenyataan. Tidak ada batasan waktu dalam ngawulo, hanya menunggu kecocokan antar kedua kemanten. Kecocokan biasanya ditandai dengan keduanya telah melakukan hubungan intim. Bila dalam waktu menunggu dapat rukun dan keduanya saling mencintai, anak laki-laki akan bilang kepada orang tua perempuan (calon mertua) dan berkata "turun sampean asli wedhok lan empun ngerti gawene" (anak bapak/ibu asli perempuan dan sudah dapat saya kawini). Akan tetapi, sebaliknya dalam waktu menunggu tidak dapat berhubungan suami istri karena anak perempuan tidak senang, perkawinan tidak jadi dilaksanakan. Apabila sudah dirasa cocok, maka selanjutnya akan dilakukan tahap peseksen.

"Nyuwita-ngawula tujuane golek kecocokan pasangan, wong urip yen arep omah-omah kudu rukun podo karone. Amergo pasangan urip kui siji sak lawase, sedulur sikep ora kenal kawin pindo dadi kudu dirukunke disik. Pancen wis soko wong mbiyen-mbiyen koyok ngono, keturunane mung nglanjutake opo sing diwarahi mbahe jaman kae".21

4. Paseksen, setelah kemanten putra dan putri melangsungkan hubungan intim suami istri (kumpul), maka keluarga dari masing-masing kemanten harus segera melaksanakan paseksen (akad nikah).

\footnotetext{
20 Wawancara, Ibu Hartatik 16 Februari 2017

21 wawancara, ibu Hartatik pada tanggal 16 Februari 2017
} 
Tahap-tahap di atas adalah tahap pernikahan adat masyarakat Samin yang masih tulen. Sejauh ini sudah banyak masyarakat Samin yang masuk Islam, hal tersebut karena masyarakat Samin menikah dengan masyarakat non Samin yang beragama Islam, sehingga pihak Samin mengikuti agama istri/suaminya yaitu Islam. Masyarakat Samin yang menikah dengan orang Islam mau mengurus pernikahannya di Kantor Urusan Agama KUA, secara otomatis jika mengurus pernikahan di KUA sudah pasti menggunakan Kartu Tanda Penduduk (KTP) sehingga mereka mau tidak mau harus mempunyai KTP. Agama yang tercantum dalam KTPnya yaitu Islam, meskipun tercantum agama Islam namun secara ketaatan dalam menjalankan agamanya wallahu a'lam. Latar belakang mereka mau membuat KTP karena berkepentingan mengurus syarat administrasi pernikahan atau meminjam uang di bank. 22

Adapun tahap pernikahan secara Islam pada masyarakat Samin yang menikah dengan orang non Samin Islam yaitu:

1. Lamaran, adalah tahap sebelum dilangsungkan pernikahan. Pihak orang tua dari mempelai laki-laki datang ke rumah calon mempelai perempuan. Biasanya Ibu dari calon mempelai laki-laki memakaikan cincin ke jari calon mempelai perempuan (calon menantu) sebagai tanda bahwa calon mempelai perempuan sudah dilamar atau dipinang oleh anak lelakinya. Dalam tahap lamaran tidak semua pasangan pernikahan silang antara Samin dan Islam melaksanakannya. Ada sebagian yang tidak melaksanakan tahap lamaran karena pihak orang tua calon mempelai laki-laki dari pihak Samin tidak setuju dengan pernikahan tersebut dan calon mempelai laki-laki tetap bersikukuh untuk menikah dengan wanita pilihannya tersebut. Sehingga calon mempelai laki-laki hanya nembung atau minta izin kepada orang tua calon mempelai wanita dan langsung mengurus pernikahannya di KUA. "Mbiyen aku ora ono acara lamaran mbak, lha piye wong Bapak Ibuku (dari pihak sikep) ora setuju nek aku ntuk wong Islam, nek pihak keluargaku ra setuju berarti kan ra iso lamaran, yowis akhire aku nembung ning Bapak e bojoku yen aku tresno mbi putrine ape tak pek bojo, yo sidane aku dewe sing ngurus ning KUA".23

2. Syahadat, adalah tahap dimana pihak Samin di Islamkan yaitu dengan cara di syahadat terlebih dahulu sebelum akad berlangsung. Pengislaman tersebut bisa dilakukan di tempat akad maupun satu minggu sebelum akad berbarengan dengan pengecekan kelengkapan

22 wawancara, Bapak Musyafa', tanggal 15 Februari 2017

${ }^{23}$ wawancara, Bapak Sumar (pihak Samin), 17 Februari 2017 
administrasi pernikahan di KUA. Untuk mengetahui bahwa pasangan tersebut dari komunitas Samin atau tidak biasanya Modin Dusun Bombong yang memberikan laporan kepada pihak KUA bahwa calon pasangan tersebut dari komunitas Samin sehingga harus di Islamkan terlebih dahulu. Dan apabila perempuan dari pihak Samin maka harus menggunakan wali hakim.

"Sudah banyak warga Samin yang masuk Islam dan menikah di KUA sini mbak, namun sayangnya secara administrasi tidak ada keterangan bahwa si A menikah dengan si B dan si B berasal dari kalangan Samin, karena secara administrasi KTP mereka sudah tercantum agama Islam. Biasanya Modin Dusun Bombong yang laporan bahwa pasangan tersebut dari kalangan Samin. Bagi pihak yang berasal dari Samin harus di Islamkan terlebih dahulu yaitu dengan cara di syahadat sebelum melaksanakan akad dan apabila mempelai wanitanya berasal dari Samin maka tidak boleh menggunakan wali orang tua kandungnya sekalipun Bapak kandungnya masih hidup, namun harus menggunakan wali hakim". 24

"Nek wong Samin kan kudu di Islamke disik mbak, biasane seminggu sak durunge akad sing ape nikah tak jak ning KUA ngurus administrasi disik, nek sing ape nikah kui ono salah sijine Samin ape nikah ntuk wong Islam yo sing Samin di syahadat disik ning KUA, tapi biasane seminggu sak durunge akad yo tak warahi disik moco syahadat". ${ }^{25}$

3. Akad nikah, adalah ijab qobul yang dilaksanakan oleh mempelai lakilaki dengan penghulu. Akad nikah dilakukan seperti akad nikah pada umumnya. Bagi mempelai perempuan apabila berasal dari kalangan Samin maka tidak bisa menggunakan wali Bapak kandungnya melainkan menggunakan wali hakim sekalipun Bapak kandungnya masih hidup.

4. Doa, biasanya setelah akad nikah diakhiri dengan doa oleh Modin dengan harapan agar pernikahan tersebut dapat menjadi keluarga yang sakinah, mawaddah, warahmah.

Berdasarkan temuan lapangan, yang berperan sebagai da'i tidak hanya laki-laki saja melainkan ada juga perempuan yang berperan sebagai da'i. Faktor utama terjadinya pernikahan diantara mereka adalah karena rasa cinta pihak sikep terhadap pasangannya sehingga dengan legowo (suka rela) pihak sikep mau masuk Islam. Sejauh ini belum ada yang berniatan dakwah dengan menikahi orang Samin agar masuk Islam.

24 wawancara, Bapak Musyafa' 15 Februari 2017 seorang penghulu di KUA Sukolilo

25 wawancara, Modin Dusun Bombong, 18 Februari 2017 
Berpijak pada UU No.1/1974 tentang Perkawinan, terdapat hal krusial yang perlu diklarifikasi. Pertama, Pasal 2 (1) tiap perkawinan dicatat menurut peraturan perundangan yang berlaku. Masyarakat Samin Bombong tidak mengenal pencatatan pernikahan karena tidak diajarkan leluhurnya. Namun masyarakat Samin yang menikah dengan orang Islam sudah mencatatkan perkawinannya sesuai dengan perundangan yang berlaku. Kedua, Pasal 7 (1) perkawinan hanya diijinkan jika pihak pria (minimal) mencapai umur 19 tahun dan pihak wanita (minimal) mencapai umur 16 tahun. Masyarakat Samin beranggapan usia calon mempelai tidak memiliki batas minimal, usia dan standar dilangsungkannya pernikahan ketika mereka siap menikah. ${ }^{26}$

Ketiga, Pasal 26 (1) perkawinan dilangsungkan di muka pegawai pencatat perkawinan yang tidak berwenang, dapat dibatalkan. Samin Bombong memegang prinsip tanpa menghadirkan petugas KUA atau Kantor Catatan Sipil karena mengikuti tradisi moyangnya. Sedangkan masyarakat Samin yang menikah dengan orang Islam melangsungkan perkawinannya di muka pegawai pencatat perkawinan yaitu di KUA. Keempat, Pasal 28 (1) batalnya perkawinan setelah keputusan pengadilan berkekuatan hukum tetap. Batalnya perkawinan versi masyarakat Samin jika kedua mempelai berpisah secara alamiah karena berbagai hal, sehingga (mantan) suami menyerahkan (mantan) istrinya kepada (mantan) mertuanya. Pernikahan Samin dengan orang Islam yang hanya menikah siri tidak memiliki kekuatan hukum sehingga apabila mereka berpisah tidak melalui jalur persidangan perceraian melainkan langsung berpisah. Kelima, Pasal 29 (1) pada waktu atau sebelum perkawinan dilangsungkan, kedua pihak atas persetujuan bersama dapat mengadakan perjanjian tertulis yang disahkan pegawai pencatat perkawinan. Masyarakat Samin pun tidak disentuh oleh budaya tulis-menulis dalam proses pernikahan karena budaya leluhurnya tidak mengajarkan pencatatan perkawinan. Masyarakat Samin yang menikah dengan orang Islam atas persetujuan kedua belah pihak calon mempelai dan juga mengurus berkas-berkas administrasi persyaratan pernikahan di KUA.27

Dalam kompilasi hukum Islam tentang wali nikah Pasal 20 (1) yang bertindak sebagai wali nikah ialah seorang laki-laki yang memenuhi syarat

26 Moh. Rosyid. "Mengevaluasi Ulang Dakwah pada Pemeluk Agama Lokal: Studi Kasus Pada Komunitas Samin", dalam Jurnal Ilmu Dakwah, Vol. 34, No.1, Januari - Juni 2014.Hlm:30.

27 Moh. Rosyid. "Mengevaluasi Ulang Dakwah pada Pemeluk Agama Lokal: Studi Kasus Pada Komunitas Samin", dalam Jurnal Ilmu Dakwah, Vol. 34, No.1, Januari - Juni 2014.HIm:30. 
hukum Islam yakni muslim, aqil dan baligh. Wali nikah dalam pernikahan masyarakat Samin dengan orang Islam apabila mempelai wanita berasal dari kalangan Samin maka menggunakan wali hakim. Tidak bisa menggunakan wali dari ayah kandungnya sekalipun ayah kandungnya masih hidup.

\section{F. Dakwah Fardiyah melalui Penikahan Islam Masyarakat Samin (Sedulur Sikep) di Dusun Bombong Desa Baturejo Kecamatan Sukolilo Kabupaten Pati}

Islam adalah agama yang membawa misi besar, yakni rahmatan lil 'alamin (rahmat bagi seluruh alam semesta). Untuk menyebarkan rahmat bagi semua ini, Islam juga membawa misi utama untuk terwujudnya kemaslahatan, keadilan, dan kebebasan. Semua aturan Islam, terutama yang tertuang dalam al-Qur'an menjadi bukti akan hal tersebut. Kalaupun kemudian muncul banyak penafsiran yang menyimpang dari misi-misi tersebut, hal ini karena adanya penafsiran terhadap al-Qur'an yang didasari oleh konteks sosial budaya yang melingkupi para penafsirnya, atau juga karena pemahaman yang literal terhadap teks-teks hadits Nabi Muhammad Saw. ${ }^{28}$

Dakwah Islam merupakan ajakan kepada orang-orang (individu, kelompok, masyarakat, bangsa) ke jalan Allah (QS al-Nahl (16); 125) atau untuk berbuat kebaikan dan menghindari keburukan (QS Ali Imran (3); 104). Dengan kata lain, dakwah Islam merupakan aktualisasi atau realisasi salah satu fungsi kodrati seorang muslim, yaitu fungsi kerisalahan berupa proses pengkondisian agar seseorang atau masyarakat mengetahui, memahami, mengimani dan mengamalkan Islam sebagai ajaran dan pandangan hidup (way of life).

Pengertian dakwah Islam tersebut menggambarkan tentang kewajiban setiap individu muslim untuk berdakwah terhadap siapapun. Artinya dakwah memiliki objek sasaran tak terbatas, dakwah bukan saja dilakukan kepada kaum muslim pada umumnya, namun juga kebanyakan dari para pendakwah melupakan mad'u tertentu yaitu salah satunya dakwah kepada kaum penghayat atau para penganut ajaran jawa tulen (kejawen). Dalam hal ini yang dimaksud dengan kaum penghayat adalah masyarakat Samin. Dakwah terhadap masyarakat muslim pada umumnya menggunakan metode ceramah atau mauidzah hasanah, bentuk dakwah seperti itu sudah pas. Namun apabila bentuk dakwah mauidzah hasanah

${ }^{28}$ Riyadi, Agus. Bimbingan Konseling Perkawinan.Yogyakarta: Ombak. 2013.Hlm:1. 
diterapkan pada masyarakat Samin yaitu kurang pas, karena masyarakat Samin memiliki karakteristik yang teguh pada ajaran nenek moyang. Sehingga bentuk dakwah pada masyarakat Samin harus sesuai dengan karakteristik mereka.

Dakwah fardiyah dapat dilaksanakan pada awal proses pernikahan sampai pasca pernikahan antara masyarakat Samin dengan Islam. Setelah proses pernikahan selesai, mempelai dari pihak Samin sudah resmi beragama Islam. Namun baru sebatas status agama saja yang berubah, pemahaman terhadap agama Islam masih minim. Hal tersebut dapat disambung dalam rumah tangga mempelai tersebut. Dakwah fardiyah dapat dilakukan dalam kehidupan sehari-hari dengan menyisipkan ajaran agama Islam secara perlahan dan memberikan pemahaman terkait ajaran Islam. Sehingga keluarga tersebut dapat mencetak keturunan yang baik dan sudah mulai mengikuti alur dan sesuai dengan ajaran agama Islam.

Dakwah fardiyah pada awal pernikahan yaitu dengan adanya pengislaman dari pihak Islam yaitu pihak KUA kepada pihak mempelai yang berasal dari masyarakat Samin. Nuansa dakwah fardiyah dalam kehidupan sehari-hari terlihat dari kutipan wawancara berikut:

"Bojoku (istri) wis tak kon nganggo krudung mbak, tapi wonge durung iso istiqomah, yo maklum mbiyene kan sikep ddine ngono kae, tapi saiki yo mulai tak kon belajar nggo krudung alonalon". 29

Begitu juga dengan kehidupan dari Bapak Sumar dan Ibu Zuadini yang mana suami berasal dari komunitas Samin dan isteri beragama Islam:

"Ono jumatan aku (suami) yo melu jumatan mbak, aku yo sholat, sing marai yo bojoku, yo wis melu koyok opo sing dilakoni wong agomo Islam, bojoku yo nukokno sarung, baju koko, peci yo wis koyok wong Islam umume". ${ }^{30}$

Berdasarkan uraian di atas, upaya strategi dakwah yang dapat diterapkan pada masyarakat Samin yaitu dakwah fardiyah, merupakan dakwah seseorang kepada orang lain. Seorang $d a^{\prime} i$ berdakwah kepada seorang mad'u dengan pendekatan personal atau dari hati ke hati. Dakwah fardiyah bisa dilakukan dengan cara langsung face to face. Dakwah fardiyah

${ }^{29}$ wawancara, Andi (Islam menikah dengan Samin), 18 Februari 2017
30 wawancara, Sumar, 18 Februari 
sangat efektif bila dilakukan secara rutin dan berkesinambungan karena seorang $d a^{\prime} i$ akan lebih terfokus perhatiannya kepada seorang atau beberapa mad'u saja. $D a^{\prime} i$ dapat memantau perkembangan pemahaman dan pengalaman agama mad'u yang menjadi sasarannya mulai dari membiasakannya beramar ma'ruf nahi munkar. ${ }^{31}$

\section{G. Analisis Dakwah Fardiyah dalam Pernikahan secara Islam pada Masyarakat Samin (Sedulur Sikep) di Dusun Bombong Desa Baturejo Kecamatan Sukolilo Kabupaten Pati}

Dakwah adalah seruan atau ajakan untuk kembali kepada jalan yang benar. Dalam hal ini jalan yang benar yaitu jalan menuju Allah SWT agar mendapatkan kebahagiaan di dunia dan akhirat. Seruan tersebut untuk mempengaruhi pola pikir, sikap maupun tindakan baik secara individual maupun kelompok dalam sosio kultural demi terwujudnya ajaran Islam disetiap segi kehidupan manusia.

Seruan/ajakan dalam dakwah fardiyah ialah upaya seorang da'i yang berusaha lebih dekat mengenai mad'u untuk dituntun ke jalan Allah. Oleh karena itu, untuk mencapai sasaran dakwah ia harus selalu menyertainya dan membina persaudaraan dengannya karena Allah. Dari celah-celah persahabatan inilah ia berusaha membawa mad'u kepada keimanan, ketaatan, kesatuan, komitmen, pada sistem kehidupan Islam dan adabadabnya, yang membuahkan sikap ta'awun (tolong menolong) dalam kebaikan dan ketakwaan, dan membiasakannya beramar ma'ruf nahi mungkar. ${ }^{32}$

Sebagaimana tercantum pada data monografi bahwa terdapat kurang lebih 800an penduduk sikep di Dusun Bombong Desa Baturejo Kecamatan Sukolilo Kabupaten Pati yang menganut agama Adam. Jumlah yang cukup padat berada di RT 01 dan RT 02 Dusun Bombong. Padatnya jumlah penduduk sikep karena perkawinan mereka dengan sesama saudara sikep sendiri, sehingga kekerabatan hanya sekeliling keluarga mereka dan semakin banyaknya keturunan sikep yang lahir. Namun sekarang sudah jauh berbeda, sudah banyak masyarakat Samin yang mulai masuk Islam.

31 Mahmud, A A Halim. Dakwah Fardiyah Metode Membentuk Pribadi Muslim. Jakarta: Gema Insani. 1995.Hlm:29.

32 Mahmud, A A Halim. Dakwah Fardiyah Metode Membentuk Pribadi Muslim. Jakarta: Gema Insani. 1995.Hlm:29. 
Jumlah penduduk yang semakin padat di pemukiman Samin membuat mudahnya orang tua Samin dalam menikahkan anaknya dengan siapapun, tidak memandang dari komunitas atau agama apapun. Apabila ada seorang laki-laki yang ingin menikahi putrinya maka dengan senang hati orang tua Samin akan menerimanya, hal tersebut berbeda dengan zaman dahulu sebelum pemukiman Samin padat penduduk. Orang tua Samin pasti menghimbau anaknya untuk menikah dengan orang yang berasal dari sama-sama Samin. Hal tersebut sebagaimana kutipan wawancara pada bab 3 berikut:

"Wong Samin wedok nek ntuk wong Islam yo ntuk digowo bojone mbak, wong tuane ora ngrawehi, yo angger dipek bojo sopo wae mesti gelem, jaman mbiyen kan ora ntuk yen anake ntuk bojo selain Samin, saiki ntuk amergo lahan semakin sempit wis padat penduduk, kan Samin modele rumahe tinggal satu blok deretan, misale anake ntuk wong njobo nek dirawehi lha terus piye, dadine saikine nek ntuk sopo wae yo gelem".33

Pola hidup keagamaan masyarakat Samin berusaha dijalani dengan tuntunan agama Islam. Hal tersebut dijalani oleh generasi penerus Samin yang telah mendapat ilmu pengetahuan dan pengertian dari pembelajaran di sekolah dan media lain yang dapat mendukung pola pikir menjadi lebih baik. Namun untuk golongan tua seperti contoh sesepuh Samin masih mempraktekkan pola hidup keagamaan yang didapat sejak dulu. Sehingga generasi penerus Samin yang masih muda banyak yang menikah dengan orang Islam. Hal tersebut didukung oleh penelitian Siti Nur Asiah pada sub bab tinjauan pustaka. Asiah membenarkan bahwa generasi penerus Samin yang telah mendapatkan ilmu pengetahuan sudah memiliki pola pikir yang lebih baik dan lebih mudah menerima tuntunan agama Islam. Dalam hal ini keterbukaan tersebut melalui jalur pernikahan secara Islam oleh masyarakat Samin dengan orang Islam. ${ }^{34}$

Mengetahui karakteristik yang demikian, maka perlu adanya sebuah strategi dakwah yang secara intensif antara $d a^{\prime} i$ dan mad'u. Karena komunikasi yang lancar dan sering bertemu dapat mempermudah pendekatan terhadap mad'u. Apabila dakwah yang biasanya dilakukan kepada sesama muslim menggunakan model ceramah maka hal tersebut

33 wawancara, Musdi (Modin Dusun Bombong), 18 Februari 2017

${ }^{34}$ Asiah, Siti Nur. 2013. Pola Hidup Keagamaan Masyarakat Samin di Era Modern (Studi Kasus di Desa Klopoduwur Kecamatan Banjarejo Kabupaten Blora, Jawa Tengah). (Skripsi tidak dipublikasikan). Yogyakarta: UIN Sunan Kalijaga. 
tidak bisa secara mentah diberikan kepada masyarakat Samin maka yaitu bisa menggunakan dakwah fardiyah.

Sebagaimana landasan teori bahwa dakwah fardiyah adalah dakwah yang dilakukan antara perorangan (satu dai dan satu mad'u). Dakwah fardiyah ini nampak pada aktivitas sehari-hari pada keluarga Samin yang sudah Islam. Nuansa dakwah fardiyah terlihat dari kecenderungan laki-laki Islam berperan sebagai da'i pada keluarganya yaitu dengan memberikan nasehat kepada istrinya untuk menjalankan perintah agama Islam. Contohnya yaitu menutup aurat dengan menggunakan jilbab, begitu juga dengan istri yang berperan sebagai da'i, dengan memberikan nasehat kepada suaminya (Samin) untuk melaksanakan sholat jumat, dan membelikan barang-barang yang dapat mendukung aktivitas beribadah kepada Allah. Bahkan penulis menjumpai pada buku nikah dari keluarga Samin yang sudah Islam Bapak Andi Silvianto dan Ibu Megawati yang mana pihak perempuan berasal dari komunitas Samin sudah menggunakan jilbab pada buku nikah tersebut. Hal tersebut menunjukkan bahwa nuansa dakwah sudah mulai terasa sejak awal pernikahan mereka.

Melihat pada bab dua landasan teori bahwa da'i adalah setiap muslim/muslimat yang melakukan aktivitas dakwah sebagai kewajiban yang melekat dan tak terpisahkan dari misinya sebagai penganut Islam sesuai dengan perintah "Balligu 'anni walau ayat" artinya sampaikanlah walau satu ayat. Menurut pengertian ini, semua muslim termasuk dalam kategori da'i, sebab ia mempunyai kewajiban menyampaikan pesan-pesan agama setidak-tidaknya kepada anak, keluarga atau pada dirinya sendiri. Pengertian da'i semacam ini lebih bersifat universal, karena semua orang Islam termasuk dalam kategori da'i. ${ }^{35}$ Dalam pengertian tersebut yang termasuk dalam kategori da'i pada konteks penelitian ini adalah pelaku perkawinan silang yang beragama Islam non Samin, Modin, dan penghulu.

Sedangkan mad'u yaitu manusia yang menjadi sasaran dakwah atau manusia penerima dakwah, baik sebagai individu maupun sebagai kelompok, baik manusia yang beragama Islam maupun tidak, atau dengan kata lain, manusia secara keseluruhan. Kepada manusia yang belum beragama Islam, dakwah bertujuan mengajak mereka untuk mengikuti agama Islam; sed angkan kepada orang-orang yang telah beragama Islam, dakwah bertujuan meningkatkan kualitas iman, Islam, dan ihsan. ${ }^{36}$ Dalam konteks penelitian ini yang berperan sebagai mad'u yaitu pelaku perkawinan silang yang berasal dari masyarakat Samin atau sedulur sikep.

35 Pimay, Awaludin. Metodologi Dakwah. Semarang: Rasail. 2006.Hlm:21-22.

${ }^{36}$ Munir dan Wahyu Ilaihi. Manajemen Dakwah. Jakarta: Kencana. 2006.HIm:23. 
Maddah (materi dakwah) adalah pesan yang disampaikan oleh da'i kepada mad'u yang mengandung kebenaran dan kebaikan bagi manusia yang bersumber Al-Qur'an dan hadits. Oleh karena itu membahas maddah dakwah adalah membahas ajaran Islam itu sendiri, sebab semua ajaran Islam yang sangat luas, bisa dijadikan sebagai maddah dakwah Islam. ${ }^{37}$ Materi dakwah yang disampaikan da'i kepada mad'u dalam praktik pernikahan silang antara Samin dan Islam adalah materi yang masih ringan, karena mad'u merupakan mualaf yang baru masuk Islam.

Materi dakwah, tidak lain adalah Islam yang bersumber dari AlQuran dan hadits sebagai sumber utama yang meliputi akidah, syariat dan akhlak dengan berbagai macam cabang ilmu yang diperoleh darinya. Maddah atau materi dakwah dapat diklasifikasikan ke dalam tiga hal pokok, yaitu sebagai berikut: 38

1. Akidah (Keimanan)

Akidah yang menjadi pesan utama dakwah ini mempunyai cirriciri yang membedakan kepercayaan dengan agama lain, yaitu: (1) keterbukaan melalui persaksian (syahadat). Persaksian atau pengucapan syahadat ini dilakukan oleh pelaku pernikahan Islam (mempelai dari Samin) sebelum akad pernikahan berlangsung. (2) cakrawala pandangan yang luas dengan memperkenalkan bahwa Allah adalah Tuhan seluruh alam, bukan Tuhan kelompok atau bangsa tertentu. (3) kejelasan dan kesederhanaan diartikan bahwa seluruh ajaran akidah baik soal ketuhanan, kerasulan, ataupun alam gaib sangat mudah untuk dipahami. Materi ini diberikan secara bertahap jika mad'u sudah mulai memahami Islam dengan baik. (4) ketahanan antara iman dan Islam atau antara iman dan amal perbuatan. Dalam ibadahibadah pokok yang merupakan manifestasi dari iman dipadukan dengan segi-segi pengembangan diri dan kepribadian seseorang dengan kemaslahatan masyarakat yang menuju pada kesejahteraannya.

2. Syariat

Syariat dalam Islam erat hubungannya dengan amal lahir (nyata) dalam rangka menaati semua peraturan atau hukum Allah SWT guna mengatur hubungan manusia dengan tuhannya dan mengatur pergaulan hidup manusia dengan manusia. Syariat dibagi menjadi dua bidang, yaitu ibadah dan muamalah. Ibadah adalah cara manusia berhubungan dengan Tuhan, sedangkan muamalah adalah ketetapan Allah yang berlangsung dengan kehidupan sosial manusia, seperti

37 Saerozi. Ilmu Dakwah. Yogyakarta: Ombak. 2013.Hlm:37.

38 Saerozi. Ilmu Dakwah. Yogyakarta: Ombak. 2013.Hlm:37-39. 
hukum warisan, rumah tangga, jual beli, kepemimpinan dan amal-amal lainnya.

Materi syariat ini diberikan oleh da'i kepada mad'u ketika menjumpai hal-hal yang berkaitan dengan aktivitas yang dituntut sesuai dengan syariat Islam. Masyarakat Samin yang awalnya tidak begitu terbuka dengan zaman modern sekarang sudah mulai terbuka dan menerima kecanggihan teknologi. Masyarakat Samin Islam juga sudah mulai bersosialisasi dengan masyarakat luas sehingga dalam urusan muamalah juga harus sudah menyesuaikan dengan syariat Islam. Pihak da'i memberikan materi dakwah berkaitan dengan hal-hal yang berurusan dengan ibadah dan muamalah. Materi tersebut disampaikan dengan cara yang sederhana dan perlahan agar mad'u mampu menerima dengan baik.

3. Materi Akhlak

Akhlak adalah bentuk jamak dari khuluq yang secara etimologi berarti budi pekerti, perangai, tingkah laku, atau tabiat. Ajaran tentang nilai etis dalam Islam disebut akhlak. Wilayah akhlak Islam memiliki cakupan luas, sama luasnya dengan perilaku dan sikap manusia. Dalam materi akhlak pihak da'i senantiasa mengingatkan kebaikan yang berkaitan dengan tingkah laku dalam aktivitas sehari-hari oleh mad'u. Sehingga dalam praktiknya pihak Samin senantiasa menjaga akhlaknya dengan cara berbuat baik kepada sesama manusia.

Da'i menyampaikan materi dakwah harus sesuai dengan tingkatan pola pikir mad'u. Masyarakat Samin termasuk dalam golongan tingkat pola pikir orang awam, sehingga da'i dalam menyampaikan materi dakwah kepada mad'u juga dengan cara yang sederhana yaitu melalui cara anjuran dan nasehat agar mudah diterima. Hal tersebut dibuktikan pada bab 3 bahwa pihak da'i (suami) menasehati mad'u (isteri) untuk menggunakan jilbab.

"Bojoku (istri) wis tak kon nganggo krudung mbak, tapi wonge durung iso istiqomah, yo maklum mbiyene kan sikep ddine ngono kae, tapi saiki yo mulai tak kon belajar nggo krudung alonalon".39

Secara umum, masyarakat sikep yang sudah mempunyai KTP mencantumkan agamanya yaitu Islam. Jika ada masyarakat sikep yang keberatan mencatatkan agama Islam maka keterangan agama dikosongi

39 wawancara, Andi (Islam menikah dengan Samin), 18 Februari 2017 
atau disetrip (-). Latar belakang mereka mau membuat KTP karena berkepentingan meminjam uang di bank. Masyarakat Samin yang menikah dengan orang Islam sudah tentu memiliki KTP.40

Berdasarkan data pernikahan masyarakat Samin dengan orang Islam pada bab tiga menunjukkan bahwa yang mendominasi adalah dari pihak laki-laki Islam menikahi wanita Samin dan kemudian dibawa ke pihak Islam. Sangat jarang sekali dari wanita Islam yang menikah dengan laki-laki Samin, bahkan pada data tersebut tercatat selama 7 tahun mulai tahun 2010 sampai 2017 hanya satu saja wanita Islam yang menikah dengan masyarakat Samin.

Pernikahan masyarakat Samin dengan Islam pada data di bab tiga cenderung naik turun. Sebenarnya dalam menentukan kecenderungan naik atau turunnya pernikahan tersebut tidak bisa dipastikan, karena pernikahan tersebut tidak selalu ada tiap tahunnya. Sehingga dalam menentukan kuantitasnya naik atau turun cukup sulit. Namun pada data tersebut menunjukkan bahwa ada pernikahan antara masyarakat Samin dan Islam di tiap tahunnya yaitu mulai tahun 2010 sampai 2016, hal tersebut cukup menggembirakan karena jumlah masyarakat Samin yang masuk agama Islam semakin bertambah.

Berdasarkan temuan lapangan, yang berperan sebagai da'i tidak hanya laki-laki saja melainkan ada juga perempuan yang berperan sebagai da'i. Faktor utama terjadinya pernikahan diantara mereka adalah karena rasa cinta pihak sikep terhadap pasangannya sehingga dengan legowo (suka rela) pihak sikep mau masuk Islam. Karena pihak Islam tidak mau apabila harus mengikuti keyakinan sikep, sehingga pihak keluarga Islam tidak akan merestui apabila sikep tidak mau ikut dalam keyakinan Islam. Hal tersebut kembali lagi kepada masing-masing individu dan kesepakatan kedua belah pihak.

Berdasarkan data hasil kutipan wawancara pada bab tiga bahwa pihak Islam memiliki kecenderungan sebagai da'i pada keluarganya. Peran da'i dalam keluarga ditunjukkan dalam bentuk nasehat kepada isteri untuk menutup auratnya yaitu dengan cara memakai jilbab. Begitu juga pada keluarga yang pihak Islamnya dari pihak perempuan, ia pun memiliki kecenderungan sebagai da'i untuk suaminya. Peran da'i tersebut ditunjukkan dalam bentuk membelikan perlengkapan untuk beribadah, misalnya sarung, baju koko, tasbih, dan peci.

Kecenderungan peran da'i pada keluarga Islam bapak Andi Silvianto (Islam) dan Ibu Megawati (Samin) bahwa dalam menyampaikan pesan

40 wawancara dengan Kepala Desa Baturejo pada tanggal 7 Maret 2017 
dakwah melalui anjuran dan nasehat kepada isterinya untuk melaksanakan perintah agama Islam. Nasehat tersebut dapat diterima isteri secara perlahan, karena isteri harus menyesuaikan dengan lingkungan Islamnya. Isteri melaksanakan perintah suaminya dengan baik, namun belum bisa istiqomah karena butuh penyesuaian dan penerimaan diri terhadap agama baru yang dianutnya, yaitu agama Islam. Bapak Andi dengan sabar menasehati Istrinya, tidak memaksa dan tidak pula mengabaikan. Sehingga proses dakwah fardiyah berjalan sesuai dengan aktivitas sehari-hari dengan menginternalisasikan ajaran agama Islam sesuai dengan syariat dalam aktivitas tersebut.

Sedangkan kecenderungan peran da'i dalam keluarga Bapak Sumar (Samin) dan Ibu Zuadini (Islam) lebih kepada praktik dan lingkungan sosial yang mendukung. Ibu Zuadini menyampaikan pesan dakwah dengan memberikan pembelajaran dan pengetahuan seputar Islam kepada suaminya. Sehingga suami belajar agama Islam dengan Isteri secara perlahan, selain itu juga didukung lingkungan sekitarnya karena mayoritas beragama Islam sehingga Bapak Sumar bersosialisasi dengan orang Islam dan mengikuti kegiatan Islam seperti mengikuti sholat jum'at. Ibu Zuadini juga mendukung proses keislaman suaminya dengan cara membelikan barang-barang yang mendukung aktivitas ibadah suaminya, yaitu dengan membelikan baju koko, sarung, peci, tasbih dan sajadah.

Ada beberapa metode dalam dakwah, sesuai dengan bab 3 bahwa metode dakwah meliputi Al-Hikmah, Al-Mauidzah hasanah, Al-Mujadalah. Al-Hikmah merupakan kemampuan dan ketepatan da'i dalam memilih, memilah dan menyelaraskan teknik dakwah dengan kondisi objektif mad'u. Secara sederhana metode dakwah Al-Hikmah yaitu berdakwah dengan memerhatikan situasi dan kondisi sasaran dakwah dengan menitik beratkan pada kemampuan mereka, sehingga di dalam menjalankan ajaran-ajaran Islam selanjutnya, mereka tidak lagi merasa terpaksa atau keberatan. ${ }^{41}$ Pada praktik dakwah masyarakat Samin Al-Hikmah dapat diterapkan karena da'i dalam menyampaikan dakwahnya sesuai dengan kondisi mad'u dan secara sederhana, agar mad'u dapat memahami dengan baik dan melaksanakan nasehat dakwah tersebut dengan baik tanpa ada rasa paksaan.

Dakwah fardiyah kepada masyarakat Samin juga perlu menggunakan wasilah (media/sarana). Wasilah untuk dakwah secara umum dan dakwah secara khusus (dalam hal ini dakwah fardiyah) tentu berbeda, jika wasilah secara umum menggunakan media yang umum juga seperti lisan, tulisan,

${ }^{41}$ Munir dan Wahyu Ilaihi. Manajemen Dakwah. Jakarta: Kencana. 2006.Hlm:34. 
lukisan, audiovisual, dan akhlak. Maka wasilah untuk dakwah fardiyah sedikit berbeda karena wasilah ini secara khusus untuk pelaksanaan dakwah fardiyah. Wasilah yang dimaksud disini adalah semua jalan yang dapat mengantarkan da'i untuk mencapai tujuan dakwah. Wasilah khusus dakwah fardiyah dilakukan sesuai dengan situasi sosial yang ada. Adapun wasilah khusus dakwah fardiyah yaitu: 42

a. Hubungan Pribadi dengan Mad'u

Hubungan ini merupakan ciri sekaligus menjadi tuntutan pokok dakwah fardiyah. Walaupun tempaknya terbatas, tetapi hal ini dapat berkembang lebih lanjut hingga pada hubungan pribadi yang sangat kokoh serta menumbuhkan rasa cinta dan saling percaya. Hubungan ini bermula dari ta'aruf, lalu dilanjutkan dengan perkenalan yang lebih dekat yang menjadikan hubungan antara penerima dakwah dan da'i bagaikan lembaran kertas yang bersih tidak tertutup oleh sesuatu apapun. Apalagi dalam hal ini dakwah fardiyah melalui pernikahan Islam, sehingga pihak da'i dan mad'u sudah memiliki kedekatan yang baik.

Tahap ta'aruf ini berhasil menumbuhkan rasa saling menyayangi, saling mencintai, dan saling memahami antara pasangan suami istri pihak Islam dan pihak Samin. Dengan demikian timbul kesamaan persepsi mengenai suatu masalah, bahkan mengenai manusia, hal atau peristiwa, dan mengenai amal serta aktivitas, kemudian tumbuh perasaan saling menjaga, saling memperhatikan, saling menolong dan membantu hingga keberadaan mad'u selalu dalam lapangan iman.

Hubungan pribadi yang demikian akan menimbulkan rasa cinta, senang melaksanakan amal untuk Islam, dan juga rasa ingin menjaga serta membimbing dalam rangka melaksanakan ketaatan kepada Allah SWT.

b. Pengertian Baik terhadap Kecenderungan Mad'u

Pengertian yang dimaksud disini adalah pengetahuan da'i tentang jiwa mad'u beserta semua sifat, watak, dan kecenderungannya. Pengertian ini terdapat dalam dakwah fardiyah melalui pernikahan karena da'i sudah mengetahui karakter mad'u melalui ta'aruf. Meskipun ta'aruf tidak begitu mendalam namun setidaknya da'i sudah mengetahui sebagian karakter mad'u. Dengan seiring berjalannya waktu maka da'i dapat memiliki pengertian yang baik terhadap mad'u.

42 Mahmud, A A Halim. Dakwah Fardiyah Metode Membentuk Pribadi Muslim. Jakarta: Gema Insani. 1995.HIm:141. 
c. Sabar terhadap Mad'u

Kesabaran dalam dakwah haruslah dimiliki oleh seorang da'i. Dalam keadaan bagaimanapun da'i tetap dituntut untuk berlaku sabar, bahkan harus tetap menghiasi dirinya dengan sifat-sifat yang baik. Tidak ada sesuatu yang lebih berbahaya bagi manusia selain kehilangan kesabaran. Karena kehilangan kesabaran akan menyebabkan kehilangan ketenangan, keseimbangan, rasionalitas dan kemampuan dalam melahirkan kebijakan-kebijakan terhadap manusia maupun terhadap sesuatu yang menjadi landasan pergaulan yang baik.

Da'i dalam menyampaikan dakwah fardiyah memiliki kesabaran dalam menghadapi mad'u, da'i menyampaikan pesan dakwah tidak dengan memaksa mad'u namun memberikan anjuran atau nasehat kepada mad'u secara perlahan dan lembut sehingga mad'u tidak merasa dipaksa oleh da'i. Contohnya yaitu seperti nasehat Bapak Andi (Islam) kepada Ibu Megawati (Islam) untuk menggunakan jilbab.

Akad pernikahan menggunakan akad secara Islam. Adapun tahapannya yaitu lamaran, setelah itu pihak sikep di syahadat terlebih dahulu, syahadat dapat dilakukan ketika akan melaksanakan akad pernikahan dan terkadang satu minggu sebelum akad sudah di syahadat terlebih dahulu dibantu oleh Modin ke KUA. Biasanya satu minggu sebelumnya Modin mengajak kedua calon pengantin untuk mengurus administrasi di KUA dan sekaligus pihak mempelai yang dari kaum sedulur sikep di syahadat terlebih dahulu. ${ }^{43}$ Apabila mempelai wanita berasal dari kalangan sikep maka tidak dapat menggunakan wali nikah ayah kandungnya melainkan harus menggunakan wali hakim. ${ }^{44}$

Berpedoman pada landasan teori bahwa metode dakwah fardiyah

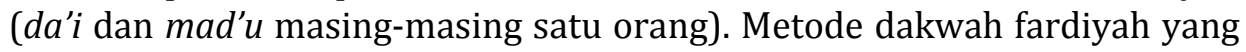
terdapat pada pernikahan silang masyarakat Samin (Islam dan Samin), antara lain:

a. Hikmah pendekatan ilmiah (jujur, berbicara sesuai objeknya, sistematis, dukungan fakta, singkat dan padat),

Hal ini pihak da'i dalam pernikahan sedulur sikep berdakwah dengan senantiasa berbicara sesuai dengan kenyataan dan jujur, sehingga membuat mad'u (sikep) percaya dengan $d a^{\prime} i$ dan mau melaksanakan arahan dari $d a^{\prime} i$. Sebagai contoh bahwa makan harus berdoa terlebih dahulu agar setan tidak ikut makan. Pihak $d a^{\prime i}$ membuat perumpamaan

43 wawancara, Musdi (Modin Dusun Bombong), 18 Februari 2017

${ }^{44}$ wawancara, Bapak Musyafa' penghulu KUA Kecamatan Sukolilo 15 Februari 
seperti itu karena pihak sikep lebih menggunakan logika sehingga dia percaya dan tidak mau setan mengganggu makannya.

b. Mauizhah hasanah (teladan baik, pelajaran yang benar),

Berdasarkan pengakuan pihak da'i bahwa ia senantiasa memberikan teladan yang baik bagi istri/suaminya (pihak sikep) agar menjadi contoh yang baik dan memberikan pembelajaran sesuai dengan syariat Islam. Mauidzah hasanah juga terdapat pada proses pernikahan silang (Samin dan Islam) yaitu pada saat akad nikah di KUA yang mana pihak Samin di syahadat terlebih dahulu.

c. Ta'aruf(pertukaran budaya positif);

Pernikahan antara pihak sedulur sikep dengan non-sikep yang beragama Islam merupakan sebuah pertukaran budaya yang positif, bahwa sedulur sikep memiliki budaya sendiri yang unik dan pihak nonsikep Islam memiliki budaya sesuai dengan syariat Islam, ketika mereka sudah menikah maka terjadi sebuah pertukaran budaya yang positif karena mereka akan mengetahui lebih dekat kebudayaan mereka satu sama lain. Kemudian mereka dapat menentukan mana yang baik dilakukan dan mana yang tidak baik dilakukan sesuai dengan tuntunan agama Islam.

d. Ishlah (perbaikan) sikap moderat sangat dituntut dalam metode ini;

Dalam praktiknya, pihak da'i tidak menuntut secara kaku bahwa pihak sikep harus mengikuti semua perintahnya, namun ia tetap menghargai pendapat pihak sikep dan memberikan sebuah pengajaran sesuai syariat Islam secara perlahan-lahan agar mudah diterima pihak sikep dan tetap memberikan kenyamanan kepada pihak sikep.

e. Tilawah (pembacaan kebenaran universal);

Dalam menjalani kehidupan berumah tangga, pihak yang beragama Islam mencoba secara terbuka dalam mengajarkan agama Islam dengan cara memberikan penjelasan mana perbuatan yang baik dilakukan dan mana yang kurang baik dilakukan.

f. Taushiyah (saling berwasiat dalam kebaikan) termasuk didalamnya kritik konstruktif;

Setelah menikah, pihak sikep dan pihak Islam saling menerima satu sama lain dan saling mengingatkan dalam kebaikan. Dalam tahap akad pernikahan, kedua mempelai mendapatkan sedikit bekal dari penghulu yaitu dengan bertausiyah atau berwasiat dalam kebaikan terutama dalam hal rumah tangga.

g. Uswah hasanah (percontohan yang baik) menyatu didalamnya bahwa ucapan dan perbuatan mesti seirama dan sama. 
Dalam hal ini pihak $d a^{\prime} i$ selalu memberikan contoh yang baik bagi suami/istrinya (pihak sikep) baik dalam hal perbuatan maupun perkataan sesuai syariat Islam, agar pihak sikep mau mengikuti dan tidak asing lagi dengan ajaran Islam.

Analisis penulis terhadap penelitian ini adalah dakwah fardiyah dilakukan dalam aktivitas sehari-hari dalam kehidupan keluarga pelaku pernikahan silang (Samin dan Islam) dengan cara menyisipkan nilai-nilai ajaran Islam secara perlahan menggunakan nasehat atau anjuran. Faktor utama yang mendorong pernikahan tersebut adalah rasa cinta antara keduanya dan pihak sikep dengan legowo (suka rela) mau masuk Islam. Namun kelemahannya disini adalah masih minimnya masyarakat non Samin beragama Islam yang secara sengaja berniat menikahi wanita Samin atas dasar dakwah, melainkan atas dasar rasa cinta.

Nuansa dakwah pada masyarakat Samin sudah terasa pada saat awal mula akan melangsungkan pernikahan. Masyarakat Samin yang dinikahi oleh orang Islam secara otomatis melakukan akad secara Islam pula, sebelum akad dilakukan, calon mempelai dari kalangan sedulur sikep di syahadat terlebih dahulu, setelah itu baru dilaksanakan akad pernikahan sebagai mana akad nikah orang Islam. Jika mempelai wanita dari kalangan sedulur sikep maka tidak bisa menggunakan orang tua kandungnya sebagai wali nikah, melainkan harus menggunakan wali hakim. ${ }^{45}$

Dakwah fardiyah dapat dilaksanakan pada awal proses pernikahan sampai pasca pernikahan. Setelah proses pernikahan selesai, mempelai dari pihak Samin sudah resmi beragama Islam. Namun baru sebatas status agama saja yang berubah, pemahaman terhadap agama Islam masih minim. Hal tersebut dapat disambung dalam rumah tangga mempelai tersebut. Dakwah fardiyah dapat dilakukan dalam kehidupan sehari-hari dengan menyisipkan ajaran agama Islam secara perlahan dan memberikan pemahaman terkait ajaran Islam. Sehingga keluarga tersebut dapat mencetak keturunan yang baik dan sudah mulai mengikuti alur dan sesuai dengan ajaran agama Islam. Namun kelemahannya disini adalah masih minimnya masyarakat non Samin beragama Islam yang secara sengaja berniat menikahi wanita Samin atas dasar dakwah, melainkan atas dasar rasa cinta.

Adapun faktor yang mendukung dalam dakwah fardiyah melalui pernikahan secara Islam tersebut adalah kesediaannya pihak Samin dalam mengikuti ajakan dari pihak Islam dalam melaksanakan perintah Allah. Meskipun belum sempurna dalam menjalankannya namun setidaknya ada

45 wawancara dengan Bapak Musyafa', 18 Februari 2017 
kemauan dari pihak Samin. Karena semua itu butuh proses yang tidak sebentar, maka pihak da'i harus senantiasa sabar dalam memberikan arahan dan tuntunan kepada pihak Samin demi terciptanya keluarga yang harmonis sakinah, mawaddah, warahmah. Sedangkan dari pihak mad'u juga harus sabar dalam menjalankan nasehat da'i dan berusaha menjalankan aktivitas dalam keluarganya dengan nuansa Islami.

Faktor penghambatnya yaitu terkadang ada rasa malas yang menggoda untuk tidak menjalankan perintah Allah. Solusinya adalah kedua belah pihak yaitu da'i dan mad'u harus sama-sama sabar, telaten dan penuh keikhlasan dalam menjalankan setiap perintah Allah. Keduanya harus menjadi partner yang mendukung satu sama lain demi terciptanya keluarga yang harmonis, sakinah, mawadah, warahmah bernuansa Islami.

\section{H. Kesimpulan dan Penutup}

Analisis penulis terhadap penelitian ini adalah kecenderungan pihak da'i dalam menyampaikan materi dakwahnya melalui nasehat pada aktivitas sehari-hari dengan menyisipkan materi agama Islam secara ringan agar mad'u dapat menerima materi dengan baik. Materi yang disampaikan secara bertahap yaitu materi yang ringan terlebih dahulu. Wasilah dalam dakwah fardiyah ini adalah hubungan pribadi yang baik dengan mad'u, perhatian yang baik terhadap mad'u serta sabar dalam menghadapi mad'u. Faktor utama yang mendorong pernikahan tersebut adalah rasa cinta antara keduanya dan pihak sikep dengan legowo (suka rela) mau masuk Islam. Namun kelemahannya disini adalah masih minimnya masyarakat non Samin beragama Islam yang secara sengaja berniat menikahi wanita Samin atas dasar dakwah, melainkan atas dasar rasa cinta. Dakwah fardiyah terhadap pernikahan masyarakat Samin merupakan sebuah solusi dakwah antarindividu dalam suatu budaya. Nuansa dakwah pada masyarakat Samin sudah terasa pada saat awal mula akan melangsungkan pernikahan. 


\section{DAFTAR PUSTAKA}

\section{Buku}

Arifuddin. 2015. Keluarga dalam Pembentukan Akhlak Islamiah.Yogyakarta: Ombak.

Aripudin, Acep. 2012. Dakwah Antarbudaya. Bandung:Remaja Rosdakarya.

Ayyub, S Hasan. 2001. Fikih Keluarga (Panduan Membangun Keluarga Sakinah sesuai Syariat. Jakarta Timur: Pustaka Al-Kautsar.

Baroroh, Umul. 2015. Fiqh Keluarga Muslim Indonesia. Semarang: CV. Karya Abadi Jaya.

Danim, Sudarwan. 2002. Menjadi Peneliti Kualitatif. Bandung : Pustaka Setia.

Departemen Agama RI. 2006. Al-Hikmah (Al-Qur'an Terjemahan). Kudus: Menara.

Djubaidah, Neng. 2010. Pencatatan Perkawinan \& Perkawinan tidak dicatat. Jakarta: Sinar Grafika Offset.

Faridl, Miftah. 1999. 150 Masalah Nikah \& Keluarga. Jakarta: Gema Insani Press.

Ismail, Ilyas dan Prio Hotman. 2011. Filsafat Dakwah:Rekayasa Membangun Agama dan Peradaban Islam. Jakarta: Kencana.

Koentjaraningrat. 1998. Pengantar Antropologi. Jakarta: Rineka Cipta. , Kompilasi Hukum Islam (Hukum Perkawinan, Kewarisan, dan Perwakafan). 2011. Bandung: Nuansa Aulia.

Kuswana, Dadang. 2011. Metode Penelitian Sosial. Bandung: Pustaka Setia.

Mahmud, A A Halim. 1995. Dakwah Fardiyah Metode Membentuk Pribadi Muslim. Jakarta: Gema Insani.

Moleong, Lexy J. 2014. Metode Penelitian Kualitatif Edisi Revisi. Bandung: PT. Remaja Rosdakarya.

Munir. 2009. Metode Dakwah Edisi Revisi. Jakarta: Kencana.

Munir dan Wahyu Ilaihi. 2006. Manajemen Dakwah. Jakarta: Kencana.

Nuh, Sayyid M. 1998. Penyebab Gagalnya Dakwah (Jilid 1). Jakarta: Gema Insani Press. 
Nuh, Sayyid M. 1998. Penyebab Gagalnya Dakwah (Jilid 2). Jakarta: Gema Insani Press.

Pimay, Awaludin. 2006. Metodologi Dakwah. Semarang: Rasail.

Purwadi dan Enis Niken. 2007. Dakwah Walisongo Penyebaran Islam Berbasis Kultural di Tanah Jawa. Yogyakarta: Panji Pustaka.

Rasyid, Muhammad Ahmad. 2002. Hambatan-hambatan Dakwah. Jakarta: Robbani Press.

Riyadi, Agus. 2013. Bimbingan Konseling Perkawinan.Yogyakarta: Ombak.

Rokhmad, Abu. 2010. Modul Metodologi Penelitian. Fakultas Dakwah IAIN Walisongo.

Saerozi. 2013. Ilmu Dakwah. Yogyakarta: Ombak.

Saputra, Wahidin. 2011. Pengantar Ilmu Dakwah. Jakarta: Rajawali Pers.

Setiawati, Effi. 2005. Nikah Sirri Tersesat di Jalan Yang Benar? Bandung : Eja Insani.

Sugiarto, Eko. 2014. Kitab EYD.Yogyakarta : Andi.

Sulthon, Muhammad. 2015. Dakwah dan Sadaqat. Yogyakarta: Pustaka Pelajar.

Supena, Ilyas. 2013. Filsafat Ilmu Dakwah. Yogyakarta:Ombak.

Syarifuddin, Amir. 2006. Hukum Perkawinan Islam di Indonesia: Antara Fiqh Munakahat dan Undang-undang Perkawinan.

Tihami dan Sohari Sahrani. 2010. Fikih Munakahat:Kajian Fikih Nikah Lengkap. Jakarta: Kharisma Putra Utama Offset

Utomo, S Laksanto. 2013. Budaya Hukum Masyarakat Samin. Bandung: PT. Alumni.

Undang-undang Dasar RI 1945

Tanya Jawab tentang Nikah Beda Agama Menurut Hukum di Indonesia. 2014. Tangerang: Penerbit Literati.

Wahono, dkk. 2002. Budi Baik Siregar dan Wahono (Ed.). Mempertahankan Nilai dari Gesekan Zaman Kembali Ke Akar. Jakarta: Forum Pengembangan Partisipasi Masyarakat. 


\section{Penelitian}

Moh. Rosyid. "Mengevaluasi Ulang Dakwah pada Pemeluk Agama Lokal: Studi Kasus Pada Komunitas Samin", dalam Jurnal Ilmu Dakwah, Vol. 34, No.1, Januari - Juni 2014.

Munadi. "Budaya Politik Masyarakat Samin (Sedulur Sikep) di dusun Bombong Desa Baturejo Kecamatan Sukolilo Pati", dalam Jurnal Ilmu Politik,Vol. 4, No. 1, Januari, 2013.

Pinasti, V. Indah, dkk, "Kajian Historisitas dan Normativitas Masyarakat Samin di Blora dalam Perspektif Pendidikan Karakter" dalam Laporan Penelitian Fundamental Universitas Negeri Yogyakarta, Oktober, 2015.

Setyo, Vidiyanti, "Faktor Pendorong Masyarakat Samin dalam Melakukan Legalisasi Status Pernikahan (Studi di Dukuh Blimbing, desa Sambongrejo, Kecamatan Sambong, Kabupaten Blora, Jawa Tengah)", dalam Jurnal Ilmu Sosial, Vol. 2, No. 7, November, 2013.

Asiah, Siti Nur. 2013. Pola Hidup Keagamaan Masyarakat Samin di Era Modern (Studi Kasus di Desa Klopoduwur Kecamatan Banjarejo Kabupaten Blora, Jawa Tengah). (Skripsi tidak dipublikasikan). Yogyakarta: UIN Sunan Kalijaga.

Haji, M. Nur. 2014. Perkawinan Adat Masyarakat Samin di Dusun Bombong Desa Baturejo Kecamatan Sukolilo Kabupaten Pati (Perbandingan antara Hukum Adat Samin dan Undang-undang nomer 1 tahun 1974 tentang perkawinan). (Skripsi tidak dipublikasikan). Yogyakarta: UIN Sunan Kalijaga.

Jannah, Siti Raudlotul. 2009. Akulturasi Budaya Ajaran Samin Surosentiko dan Islam di Desa Blimbing Kecamatan Sambong Kabupaten Blora. (Skripsi tidak dipublikasikan). Yogyakarta: UIN Sunan Kalijaga.

Mujib, Muchammad Abdul. 2014. Pandangan Hukum Islam terhadap Pernikahan Rodho'ah (Tunggal Medayoh) (Studi Kasus Pada Masyarakat Samin di Desa Baturejo Kecamatan Sukolilo Kabupaten Pati). (Skripsi tidak dipublikasikan). Semarang: UIN Walisongo. 